\title{
PENGARUH KOMUNIKASI, MOTIVASI, DAN KEDISIPLINAN TERHADAP PRESTASI BELAJAR MAHASISWA
}

\author{
Sunarsih ${ }^{1)}$, Desvira Zain ${ }^{2)}$, \& Sulaiman ${ }^{3)}$ \\ ${ }^{1}$ Jurusan Administrasi Bisnis Politeknik Negeri Pontianak \\ email: sunarsihhelmi@yahoo.com \\ 2 Jurusan Administrasi Bisnis Politeknik Negeri Pontianak \\ email: desvirazain@yahoo.com \\ ${ }^{3}$ Jurusan Administrasi Bisnis Politeknik Negeri Pontianak \\ email: imansulaiman137@yahoo.co.id
}

\begin{abstract}
This study aims to determine the effect of communication, motivation and discipline on student learning achievement majoring in business administration. In this study, the sample was 88 people from a population of 750 people who were taken randomly, using regression analysis. Sources of data obtained are primary data and secondary data. With a quantitative approach. Data collection techniques through interview techniques, observation and documentation. The data analysis technique is by means of assumption test, descriptive analysis and statistical analysis with linear regression using the help of SPSS (Social Sciences Program Statistics) version 22.0. From the research that has been done, it shows that communication, motivation and discipline on student achievement of majoring in business administration have a significant effect. Communication, motivation and discipline influence student achievement so that educators / lecturers continue to improve student readiness in the learning process so that they can be maximized so as to improve student achievement. The potential of students must continue to be developed so that it becomes a complete achievement.
\end{abstract}

Keywords: Achievement, Communication, Discipline, Learning, Motivation.

\section{PENDAHULUAN}

Perkembangan dunia Pendidikan saat ini sangat tinggi, kita di tuntut untuk terus berkembang dalam mencari ilmu dan wawasan dalam menjalani pendidikan, baik ilmu yang di peroleh secara formal maupun non formal. Kehadiran mahasiswamahasiswa di kampus tentunya ingin mengali ilmu sebanyak-banyaknya atau seluas-luasnya, hal inilah yang menjadi pantukan bagi setiap perguruan tinggi untuk mewujudkan semua programprogram yang dicanangkan oleh pemerintah yang diharapkan generasi generasi lebih berperan aktif berdasarkan ilmu yang di peroleh di bangku kuliah.

Di dalam nuansa kependidikan, manusia adalah sasaran pendidikan sekaligus subjek pendidikan. Pendidikan membantu manusia dalam menumbuh kembangkan potensi-potensi kemanusiaan yang ada dalam dirinya. Potensi kemanusiaan merupakan benih untuk mengembangkan seseorang menjadi manusia seutuhnya. Pemahaman dari pendidik terhadap potensi-potensi dan sifat hakikat manusia sangat penting agar pendidikan mencapai tujuan yang diharapkan yaitu memanusiakan manusia. Pendidikan harus diarahkan kepada pencapaian tujuan itu melalui perumusan dan penerapan konsep pendidikan.

Menurut Handoko (2002:30) mengemuka kan bahwa komunikasi adalah proses pemindahan pengertian dalam bentuk gagasan, informasi dari seseorang ke orang lain. 
Menurut Sinambela (2016:511), bahwa: "Komunikasi adalah suatu proses pembentukan, penyampaian, penerimaan, dan pengolahan pesan yang terjadi di dalam diri seseorang dan/atau di antara dua atau lebih dengan tujuan tertentu".

Komunikasi proses pembentukan dalam penyampaian maupun penerimaan dalam pengolahan pesan dalam diri seseorang.

Menurut Winardi (2002:2) mengemuka kan "motivasi merupakan hasil sejumlah proses, yang bersifat internal, atau eksternal bagi seorang individu yang menyebabkan timbulnya sikap entusiasme dan persistensi, dalam hal melaksanakan kegiatan-kegiatan tertentu.

Pendisiplinan adalah usaha usaha untuk menanamkan nilai ataupun pemaksaan agar subjek memiliki kemampuan untuk menaati sebuah peraturan. Pendisiplinan bisa jadi menjadi istilah pengganti untuk hukuman ataupun instrumen hukuman dimana hal ini bisa dilakukan pada diri sendiri ataupun pada orang lain.

Menurut Hasibuan (2002) Disiplin ialah suatu sikap menghormati dan menghargai suatu peraturan yang berlaku, baik secara tertulis maupun tidak tertulis serta sanggup menjalankannya dan tidak menolak untuk menerima sanksi-sanksi apabila dia melanggar tugas dan wewenang yang diberikan kepadanya.

Dalam penelitian ini peneliti mengembang kan dunia pendidikan, apakah ada Pengaruh antara Komunikasi, Motivasi dan Kedisiplinan terhadap Prestasi Belajar pada Mahasiswa Jurusan Administrasi Bisnis Politeknik Negeri Pontianak.

Perkembangan Penelitian yang dilakukan sampai saat sudah berjalan sesuai rencana peneliti. Di dalam penelitian ini yang menjadi responden adalah mahasiswa di Jurusan Administrasi Bisnis. Mahasiswa yang diambil ada 3 prodi yaitu prodi Administrasi Bisnis, prodi Administrasi Otomotif dan Prodi Administrasi Negara. Responden secara sampel berjumlah 88 orang dan diambil secara keseluruhan dari sampel tersebut dengan kriteria IPK tertinggi di tiap kelas masing-masing berdasarkan program studi.

\section{METODE PENELITIAN}

\section{a. Pendekatan Penelitian}

Dalam penelitian ini menggunakan pendekatan penelitian kuantitatif yaitu peneliti mengumpulkan data dengan menetapkan terlebih dahulu konsep sebagai variabel-variabel yang berhubungan yang berasal dari teori yang sudah ada yang diperoleh oleh peneliti dan kemudian mencari datanya dengan menggunakan kuesioner untuk pengukuran variabelvariabel.

Dari penelitian sebelumnya oleh Syamsu Alam (2019) berjudul "Pengaruh Komunikasi, Motivasi dan Disiplin Kerja Terhadap Kinerja Pegawai Lembaga Penjamin Mutu Pendidikan". (Program Studi Magister Managemen Pascasarjana Universitas Tadulako), dengan hasil Komunikasi Motivasi dan Disiplin Kerja Terhadap Kinerja Pegawai Lembaga Penjamin Mutu Pendidikan berpengaruh positif dan signifikan terhadap kinerja Pegawai Lembaga Penjamin Mutu Pendidikan.

Denok Sunarsi (2018). Berjudul" Pengaruh Disiplin, Motivasi dan Kompetensi Terhadap Prestasi Belajar (Studi Kasus Pada Mahasiswa Universitas Pamulang, Tangerang Selatan Tahun Akademik 2016-2017)". Hasil disiplin Motivasi dan Kompetensi Terhadap Prestasi Belajar berpengaruh positif dan signifikan terhadap prestasi belajar.

\section{b. Jenis Penelitian}

Berdasarkan tujuan penelitian yang ditetapkan, maka penelitian ini adalah penelitian eksplanatori (Explanatory Research) yaitu penelitian yang menyoroti hubungan antara variabel-variabel penelitian dan menguji hipotesis yang telah dirumuskan (Singarimbun dan Effendi, 1995: 86 ). 


\section{c. Populasi}

Populasi adalah Keseluruhan nilai atau sumber data yang mungkin diperoleh melalui hasil perhitungan atau pengukuran, baik yang bersifat kuantitatif maupun yang bersifat kualitatif dari karakteristik tertentu mengenai sekumpulan objek yang lengkap dan jelas yang ingin dipelajari dan dianalisa sifat-sifatnya. Dalam penelitian ini yang menjadi populasi adalah para mahasiswa jurusan administasi bisnis

\section{d. Sampel}

Menurut Umar (2004:107) sampel adalah sebagian dari jumlah dan karakteristik yang dimiliki oleh populasi.

Dalam penelitian ini yang menjadi sampel adalah 88 orang mahasiswa yang IPK Tinggi, diambil representatif maka dihitung dengan menggunakan rumus Slovin dalam Umar (2004 : 108) dengan presisi $10 \%$, rumusnya sebagai berikut:

$$
\mathbf{n}=\frac{N}{1+N(e)^{2}}
$$

\section{Dimana:}

$$
\begin{aligned}
\mathrm{n}= & \text { jumlah sampel } \\
\mathrm{N}= & \text { jumlah populasi } \\
\mathrm{e}= & \text { persen kelonggaran ketidaktelitian } \\
& \text { karena kesalahan pengambilan } \\
& \text { sample yang masih dapat ditolerir } \\
& \text { atau diinginkan. }
\end{aligned}
$$

Berdasarkan rumus tersebut, maka jumlah sampel yang diperoleh adalah:

$$
\begin{gathered}
\mathrm{n}=\frac{750}{1+(100)(0,1)^{2}} \\
=88
\end{gathered}
$$

\section{e. Sumber Data}

Jenis data penelitian ada dua, yakni : data primer dan data sekunder. Karena yang diteliti adalah perilaku responden maka data utama yang diperlukan adalah untuk mendukung hipotesis penelitian ini adalah data primer. Data primer adalah data orang pertama yakni data yang berasal langsung dari sumber data yang dikumpulkan secara khusus dan berkaitan langsung dengan permasalahan yang diteliti. Sumber data primer pada penelitian adalah Para mahasiswa yang ada di Jurusan Administrasi Bisnis yang terdiri dari 3 prodi yaitu prodi Administrasi Bisnis, Prodi Administradi Negara dan Prodi Administrasi Otomotif.

Selain data primer, digunakan juga data sekunder untuk mendukung penelitian ini. Sumber data sekunder yang dimaksud adalah buku-buku, jurnal ilmiah, majalah, literatur dan internet yang berkaitan dengan objek penelitian.

\section{f. Teknik Pengumpulan Data}

Pengumpulan data dalam penelitian ini dilakukan melalui teknik wawancara, kuesioner, dan studi dokumentasi.

a) Wawancara digunakan untuk mengetahui kondisi dan fakta yang terjadi di lokasi penelitian. Data sekunder ini di dapat dari beberapa pihak dalam organisasi.

b) Kuesioner adalah daftar pertanyaan yang diajukan kepada responden untuk memperoleh data yang berkaitan dengan penelitian. Kuesioner ini dimaksudkan untuk memperoleh data deskriptif dalam menguji hipotesis. Pengumpulan data dilakukan dengan cara membagikan kusioner tersebut kepada para mahasiswa jurusan administrasi bisnis Responden kemudian diminta mengisi kuesioner sesuai dengan petunjuk yang telah tersedia.

c) Studi Dokumentasi. Penelaahan data dengan jalan mengumpulkan informasiinformasi melalui, dokumen-dokumen atau arsip-arsip yang berupa laporanlaporan maupun catatan yang tersedia di organisasi dan sesuai dengan permasalahan.

Data yang sudah terkumpul dari responden diolah dengan skala Likert. Skala Likert umumnya digunakan untuk menilai pendapat atau persepsi dari responden tentang perilaku dan fenomena sosial yang dipakai oleh peneliti dalam 
variabel penelitian. Analisa diawali dengan data responden dan kemudian diukur tingkat kepentingan responden terhadap indikator-indikator yang diajukan dalam kuesioner dengan menggunakan skala 5 tingkat (Riduwan, 2006 : 20-21). Menggunakan skala Likert yaitu untuk mengukur sikap dan persepsi seseorang atau kelompok tentang kejadian atau gejala sosial. Dalam penelitian ini, penulis tidak menggunakan item ragu-ragu atau netral karena di khawatirkan jawaban responden akan mengarah ke jawaban tersebut, yang dapat membuat penelitian ini menjadi bias. Oleh karena itu (1) Sangat Tidak Setuju, (2) Tidak Setuju, (3) Kurang Setuju, (4) Setuju, dan (5) Sangat Setuju.

\section{Uji Validitas}

Uji validitas digunakan untuk menguji instrument agar memberikan hasil sesuai dengan tujuan. Menurut Supardi (2005 : 156), validitas menunjukkan tingkat instrument penelitian penelitian mengukur apa yang diinginkan dan dapat mengungkapkan data dan variabel yang diteliti secara tepat. Pengujian validitas dilakukan dengan analisa butir. Sebuah instrumen dikatakan valid, jika koefisien korelasinya $\geq 0,3$ dengan $\alpha 0,05$. Untuk menguji validitas responden digunakan rumus korelasi "product moment", dengan rumus sebagai berikut :

$$
=\frac{r_{x y}}{\left.\sqrt{\left(n \sum x^{2}\right.}-\left(\sum x\right)^{2}\right)\left(n\left(\sum y^{2}\right)-\left(\sum y\right)^{2}\right)}
$$

Dimana:

$\mathrm{r}=$ koefisien korelasi

$\mathrm{x}=$ skor jawaban tiap item

$\mathrm{y}=$ skor total

$\mathrm{n}=$ jumlah responden

Jika $t_{\text {hitung }}>t$ tabel, berarti valid

Jika $t_{\text {hitung }}<\mathrm{t}$ tabel, berarti tidak valid

\section{Uji Reliabilitas}

Menurut Supardi (2005 : 159), Reliabilitas mengarah pada keajegan suatu alat ukur, di mana tingkat reliabilitas memperhatikan sejauh mana alat ukur dapat diandalkan dan dipercaya. Bila suatu alat pengukur dipakai dua kali untuk mengukur gejala yang sama dan hasil pengukuran yang diperoleh relatif konsisten, maka alat pengukur tersebut reliabel. Dengan kata lain, reliabilitas menunjukkan konsistensi suatu alat pengukur di dalam mengukur alat yang sama.

Menurut Arikunto (2002 : 160), instrumen dikatakan andal (reliabel) apabila memiliki keandalan sebesar 0,60 atau lebih. Uji reliabilitas ini dilakukan dengan menggunakan teknik alpha cronbach $(\alpha)$, dengan rumus sebagai berikut :

$r_{11}=\left[\frac{k}{k-1}\right]\left[1-\frac{\sum a^{2} b}{a^{2} 1}\right]$

Dimana :

$\mathrm{r}_{11}=$ reliabilitas instrumen

$\mathrm{k} \quad=\quad$ banyaknya butir pertanyaan

$$
\begin{array}{cl}
\sum \alpha^{2} \mathrm{~b} & =\text { jumlah varians butir } \\
\alpha^{2} 1 & =\text { varians total }
\end{array}
$$

Kriteria indeks reabilitas menurut Arikunto (2002 : 161) sebagai berikut :

\begin{tabular}{|c|c|c|}
\hline No. & Interval & Kriteria \\
\hline 1. & $<0,200$ & Sangat rendah \\
2. & $0,200-0,399$ & Rendah \\
3. & $0,400-0,599$ & Cukup \\
4. & $0,600-0,779$ & Tinggi \\
5. & $0,800-1,00$ & Sangat Tinggi \\
\hline
\end{tabular}

Sumber : Arikunto, 2002

\section{Uji Asumsi Klasik}

Model regresi berganda dapat disebut model yang baik jika model tersebut memenuhi asumsi normalitas data dan terbebas dari asumsi-asumsi klasik statistik. Uji asumsi klasik dilakukan meliputi uji heteroskedastisitas, uji normalitas dan uji multikolonieritas. Beberapa uji asumsi klasik yang dipergunakan antara lain adalah sebagai berikut : 


\section{a) Uji Heteroskedastisitas}

Menurut Santoso (2000:208), Uji heteroskedasitas bertujuan untuk menguji apakah dalam model regresi terjadi ketidaksamaan variance dari residual pengamatan ke pengamatan yang lain. Menurut Santoso (2000:210), Jika variance dari residual satu pengamatan ke pengamatan lain tetap, maka disebut homoskedastisitas dan jika berbeda disebut heteros kedastisitas.

Teknik pengujian dilakukan dengan Scatter Plot Diagram (diagram pencar) dengan ketentuan apabila titik-titik pada Scatter Plot Diagram menyebar secara acak di atas dan di bawah angka 0 pada sumbu y dan tidak membentuk pola tertentu maka dapat dikatakan tidak terjadi heteroskedastisitas.

\section{b) Uji Normalitas}

Menurut Santoso (2000:212), Uji normalitas digunakan untuk mendeteksi apakah distribusi data variabelnya adalah normal. Pengujian distribusi normal ini digunakan normal probability plot. Sebaran normal merupakan sebuah pendekatan fungsi dari suatu kumpulan yang memiliki ciri khas, seperti pengamatan yang paling banyak dijumpai memiliki nilai di sekitar nilai tengah (mean), pengamatan yang sangat jauh (ke arah kanan dan kiri mean) berjumlah sedikit sekali, memiliki pola yang simetris. Menurut Santoso (2000:214), Salah satu cara untuk menguji kenormalan adalah Uji Chi Square, untuk menentukan apakah sebaran data normal atau tidak, dapat dilihat dan nilai probabilitas dibandingkan dengan $\alpha$. Jika nilai probabilitas $<\alpha$ berarti data tersebar normal.

\section{c) Uji Multikolonieritas}

Uji multikolinearitas digunakan untuk menguji apakah antar variabel independen yang terdapat dalam model memiliki hubungan yang sempurna atau mendekati sempurna (koefisien korelasinya tinggi atau bahkan 1). Menurut Santoso (2000:203), Model regresi yang baik adalah yang tidak terdapat multikolinieritas. Pengujian dilakukan dengan melihat Variance Inflation Factor (VIF). Menurut Santoso (2000:206), Jika VIF lebih besar dari 10, maka variabel tersebut memiliki persoalan Multikolinieritas dengan variabel bebas lainnya.

\section{g. Kerangka Pemikiran}

Kerangka pemikiran merupakan suatu urutan-urutan logis dari peneliti untuk menyelesaikan suatu masalah dalam penelitian yang di tuangkan dalam bentuk bagan dan di operasionalisasikan serta penjelasannya, yang di ambil berdasarkan indikator dari masing-masing variabel . Dimana bentuk bagan dapat di lihat pada Gambar 1 di bawah ini.

Mengingat kerangka pemikiran tersebut sifatnya masih abstrak maka perlu dioperasionalisasikan menjadi variabelvariabel dan item-item menurut indikatorindikator yang ditetapkan, sebagai berikut :

\begin{tabular}{|c|c|c|c|}
\hline Konsep & Variabel & Indikator & Item \\
\hline $\begin{array}{l}\text { Kemampuan } \\
\text { mahasiswa } \\
\text { dalam } \\
\text { merahi } \\
\text { prestasi } \\
\text { belajar }\end{array}$ & $\begin{array}{l}\text { Komunikasi } \\
\text { (X1) }\end{array}$ & $\begin{array}{l}\text { 1. Pemahaman } \\
\text { 2. Kesenangan } \\
\text { 3. Pengaruh pada sikap } \\
\text { 4. Hubungan Yang makin baik }\end{array}$ & $\begin{array}{l}\text { 1. Cepat paham } \\
\text { 2. Suka dengan sesuatu hal } \\
\text { 3. Perubahan kelihan pada tingkah } \\
\text { lakunya } \\
\text { 4. Ada perubahan pada diri } \\
\text { terhadap orang lain }\end{array}$ \\
\hline
\end{tabular}




\begin{tabular}{|c|c|c|c|}
\hline Konsep & Variabel & Indikator & Item \\
\hline \multirow[t]{3}{*}{$\begin{array}{l}\text { Kemampuan } \\
\text { mahasiswa } \\
\text { dalam } \\
\text { merahi } \\
\text { prestasi } \\
\text { belajar }\end{array}$} & $\begin{array}{l}\text { Motivasi } \\
(\mathrm{X} 2)\end{array}$ & $\begin{array}{l}\text { 1. Kebutuhan Fisik } \\
\text { 2. Kebutuhan Rasa Aman } \\
\text { 3. Kebutuhan Sosialisasi } \\
\text { 4. Kebutuhan akan penghargaan } \\
\text { 5. Kebutuhan Aktulisasi }\end{array}$ & $\begin{array}{l}\text { 1. Kondisi jiwa raga } \\
\text { 2. Suasana lingkungan aman } \\
\text { tentram } \\
\text { 3. Seseorang ingin di kenal } \\
\text { 4. Sesorang ingin dihargai setiap } \\
\text { usaha yang dia lakukan } \\
\text { 5. Ingin terdepan dalam segala hal }\end{array}$ \\
\hline & $\begin{array}{l}\text { Kedisiplinan } \\
\text { (X3) }\end{array}$ & $\begin{array}{l}\text { 1. Disiplin Waktu } \\
\text { 2. Disiplin Peraturan } \\
\text { 3. Disiplin Tanggung Jawab }\end{array}$ & $\begin{array}{l}\text { 1. Tepat Waktu } \\
\text { 2. Taat peraturan } \\
\text { 3. Siap menjalankan tugas yang } \\
\text { diberikan. }\end{array}$ \\
\hline & $\begin{array}{l}\text { Prestasi } \\
\text { Belajar (Y) }\end{array}$ & $\begin{array}{ll}\text { a. } & \text { Faktor Internal } \\
& \text { - Jasmani } \\
\text { - } & \text { Psikologis } \\
\text { - Kelelahan } \\
\text { b. }\end{array}$ & $\begin{array}{l}\text { 1. Sehat jasmani } \\
\text { 2. Sehat dalam kejiwaan } \\
\text { 3. Tidak dalam kondisi kelelahan } \\
\text { 4. Dukungan keluarga, bimbingan } \\
\text { orang tua } \\
\text { 5. Pengajaran, kurikulum, fasilitas } \\
\text { 6. Lingkungan, teman dan media } \\
\text { massa }\end{array}$ \\
\hline
\end{tabular}

Sumber : Olahan data indikator

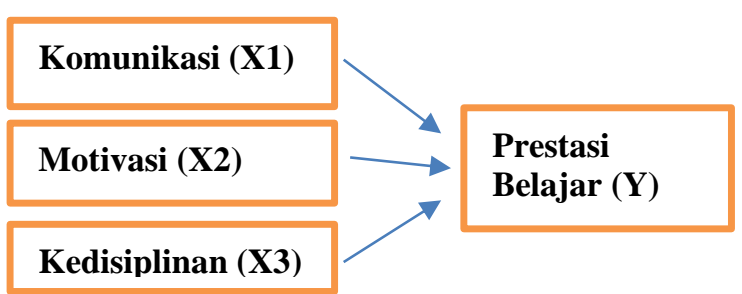

Gambar 1 : Kerangka Pemikiran

\section{h. Penyajian Data}

Penyajian data ini merupakan hasil kuesioner yang telah disebarkan oleh peneliti sebanyak 88 responden, yang terdiri dari data pribadi responden dan data variabel penelitian yang berupa jawaban responden terhadap pernyataan yang diajukan pada kuisioner yang kemudian diolah menggunakan software statistic.

Responden yang diambil dalam penelitian ini adalah mahasiswa jurusan administrasi bisnis yang memiliki IPK tertinggi dengan jumlah sebanyak 88 orang. Karakteristik responden ini meliputi jenis kelamin, program studi, dan semester.

\section{1) Jumlah Responden Berdasarkan Jenis Kelamin}

Identitas responden berdasarkan jenis kelamin pada penelitian ini disajikan pada tabel berikut ini:

\begin{tabular}{|c|l|c|c|}
\hline No & $\begin{array}{c}\text { Jenis } \\
\text { Kelamin }\end{array}$ & $\begin{array}{c}\text { Jumlah } \\
\text { (Responden) }\end{array}$ & $\begin{array}{c}\text { Persentase } \\
(\mathbf{\%})\end{array}$ \\
\hline 1 & Pria & 22 & $25 \%$ \\
\hline 2 & Wanita & 66 & $75 \%$ \\
\hline \multicolumn{2}{|c|}{ Jumlah } & 88 & $100 \%$ \\
\hline
\end{tabular}

Sumber: Data Primer (Angket) yang diolah

Berdasarkan tabel diatas dapat dijelaskan bahwa responden berdasarkan jenis kelamin pada penelitian ini sebagian besar adalah wanita berjumlah 66 responden $(75 \%)$ sedangkan $25 \%$ nya lagi dari kalangan pria yaitu berjumlah 22 responden. 


\section{2) Jumlah Responden Berdasarkan Program Studi \\ Identitas responden berdasarkan} program studi pada penelitian ini disajikan pada tabel berikut ini:

\begin{tabular}{|l|l|c|c|}
\hline No & \multicolumn{1}{|c|}{$\begin{array}{c}\text { Program } \\
\text { Studi }\end{array}$} & $\begin{array}{c}\text { Jumlah } \\
\text { (Responden) }\end{array}$ & $\begin{array}{c}\text { Persentase } \\
(\mathbf{\%})\end{array}$ \\
\hline 1 & $\begin{array}{l}\text { Administrasi } \\
\text { Bisnis }\end{array}$ & 40 & $45 \%$ \\
\hline 2 & $\begin{array}{l}\text { Administrasi } \\
\text { Bisnis } \\
\text { Otomotif }\end{array}$ & 8 & $10 \%$ \\
\hline 3 & $\begin{array}{l}\text { Administrasi } \\
\text { Negara }\end{array}$ & 40 & $45 \%$ \\
\hline \multicolumn{2}{|l|}{ Jumlah } & 88 & $100 \%$ \\
\hline
\end{tabular}

Sumber: Data Primer (Angket) yang diolah

Berdasarkan Tabel 2 di atas dapat dijelaskan bahwa responden berdasarkan program studi adalah administrasi bisnis 40 responden $(45 \%)$, administrasi bisnis otomotif 8 responden (10\%) sedangkan 45\%-nya lagi dari program studi administrasi negara yaitu berjumlah 40 responden.

\section{a. Jumlah Responden Berdasarkan Semester}

Identitas responden berdasarkan program studi pada penelitian ini disajikan pada tabel berikut ini:

\begin{tabular}{|c|l|c|c|}
\hline No & Semester & $\begin{array}{c}\text { Jumlah } \\
\text { (Responden) }\end{array}$ & $\begin{array}{c}\text { Persentase } \\
(\%)\end{array}$ \\
\hline 1 & Dua & 28 & $32 \%$ \\
\hline 2 & Empat & 25 & $28 \%$ \\
\hline 3 & Enam & 25 & $28 \%$ \\
\hline 4 & Delapan & 10 & $12 \%$ \\
\hline \multicolumn{2}{|c|}{ Jumlah } & 88 & $100 \%$ \\
\hline
\end{tabular}

Sumber: Data Primer (Angket) yang diolah

Berdasarkan Tabel di atas dapat dijelaskan bahwa responden berdasarkan semester adalah semester dua sebanyak 28 responden (32\%), semester empat sebanyak 25 responden (28\%), semester enam sebanyak 25 responden (28\%), sedangkan $12 \%$ nya lagi semester delapan yaitu berjumlah 10 responden.

\section{A. Deskripsi Data Variabel Penelitian}

Dalam penelitian ini, penulis menyebarkan kuisioner kepada responden, dimana dalam kuisioner tersebut terdapat, beberapa pernyataan yang meliputi variabel bebas yakni Komunikasi (X1) terdiri dari 10 pernyataan, Motivasi (X2) terdiri dari 10 pernyataan, Kedisiplinan (X3) terdiri dari 10 pernyataan, sementara variabel terikat yakni Prestasi Belajar (Y) juga terdiri dari 10 pernyataan, dimana hasilnya sebagai berikut:

\section{Variabel Komunikasi (X1)}

Pengukuran variabel Komunikasi dalam penelitian ini, peneliti menggunakan 4 indikator yang kemudian disajikan ke dalam 10 pernyataan. Pada setiap pernyataan terdapat 5 jawaban, dimana responden diharuskan menentukan jawaban mereka atau memilih salah satu alternatif jawaban yang telah disediakan oleh peneliti. Berdasarkan jawaban responden dari penyebaran kuisioner maka diperoleh data sebagai berikut:

Dari Tabel tersebut dapat dikemukakan sebagai berikut:

a. Item 1: adalah Setiap berkomunikasi dengan teman di kampus saya memahami maksud dari pembicaraan menunjukkan bahwa sebanyak $25 \%$ dari responden menjawab sangat setuju, $69,3 \%$ menjawab setuju, $3,4 \%$ menjawab kurang setuju, 2,3\% menjawab tidak setuju, dan $0 \%$ menjawab sangat tidak setuju. Maka dapat dikemukakan responden sudah setuju bahwa setiap berkomunikasi dengan teman di kampus responden memahami maksud dari pembicaraan. Karena dengan komunikasi yang baik, akan lebih mudah memahami setiap pembicaraan yang ada.

b. Item 2: adalah Bagi saya komunikasi sesama teman penting untuk pembersatukan keputusan yang diambil menunjukkan bahwa sebanyak $64,8 \%$ dari responden 
menjawab sangat setuju, 35,2\% menjawab setuju, 0\% menjawab kurang setuju, tidak setuju dan sangat tidak setuju. Maka dapat dikemukakan responden sangat setuju bahwa komunikasi sesama teman itu penting untuk pembersatukan keputusan yang diambil. Karena dengan komunikasi sesama teman informasi yang didapat lebih lengkap.

c. Item 3: adalah Saya senang saat melakukan diskusi karena komunikasinya jelas menunjukkan bahwa sebanyak 34,1 \% dari responden menjawab sangat setuju, $59,1 \%$ menjawab setuju, $13,6 \%$ menjawab kurang setuju, $1,1 \%$ menjawab tidak setuju dan $0 \%$ menjawab sangat tidak setuju. Maka dapat dikemukakan responden setuju bahwa senang saat melakukan diskusi karena komunikasinya jelas. Karena dengan komunikasi yang jelas mahasiswa akan senang untuk selalu berdiskusi.

d. Item 4: adalah Dalam komunikasi sesama teman ada suatu kesenangan yang saya dapati menunjukkan bahwa sebanyak $34,1 \%$ dari responden menjawab sangat setuju, $59,1 \%$ menjawab setuju, $6,8 \%$ yang menjawab kurang setuju, $0 \%$ yang menjawab tidak setuju dan sangat tidak setuju. Maka dapat dikemukakan responden setuju bahwa dalam komunikasi sesama teman ada suatu kesenangan yang responden dapati.

e. Item 5: adalah Saya paham setiap pembicaraan saat pembelajaan di kelas menunjukkan bahwa sebanyak $11,4 \%$ dari responden menjawab sangat setuju, 59,1\% menjawab setuju, 28,4\% yang menjawab kurang setuju, $1,1 \%$ yang menjawab tidak setuju dan $0,0 \%$ sangat tidak setuju. Maka dapat dikemukakan responden setuju bahwa responden paham dalam setiap pembicaraan saat pembelajaran di kelas.

f. Item 6: adalah Saya paham materi yang disampaikan dosen karena komunikasi nya jelas dan mudah di mengerti menunjukkan bahwa sebanyak $18,2 \%$ dari responden menjawab sangat setuju, 54,2\% menjawab setuju, 26,1\% yang menjawab kurang setuju, $1,1 \%$ yang menjawab tidak setuju dan $0,0 \%$ sangat tidak setuju. Maka dapat dikemukakan responden setuju bahwa responden paham materi yang disampaikan dosen karena komunikasinya jelas.

g. Item 7: adalah Bagi saya komunikasi sangat penting karena mempengaruhi sikap saya dalam proses belajar menunjukkan bahwa sebanyak $59,1 \%$ dari responden menjawab sangat setuju, 40,9\% menjawab setuju, $0 \%$ yang menjawab kurang setuju, $0 \%$ yang menjawab tidak setuju dan $0,0 \%$ sangat tidak setuju. Maka dapat dikemukakan responden sangat setuju bahwa komunikasi sangat penting karena mempengaruhi sikap saya dalam proses belajar.

h. Item 8: adalah Bagi saya dengan komunikasi yang baik akan menjalin hubungan yang baik pula menunjukkan bahwa sebanyak $65,9 \%$ dari responden menjawab sangat setuju, $34,1 \%$ menjawab setuju, $0 \%$ yang menjawab kurang setuju, $0 \%$ yang menjawab tidak setuju dan $0,0 \%$ sangat tidak setuju. Maka dapat dikemukakan responden sangat setuju bahwa dengan komunikasi yang baik akan menjalin hubungan yang baik pula.

i. Item 9: adalah Bagi saya komunikasi sesama teman di dalam kelas dan di luar kelas akan menciptakan hubungan yang mangkin baik menunjukkan bahwa 
sebanyak 53,4\% dari responden menjawab sangat setuju, 43,2\% menjawab setuju, 3,4\% yang menjawab kurang setuju, $0 \%$ yang menjawab tidak setuju dan $0,0 \%$ sangat tidak setuju. Maka dapat dikemukakan responden sangat setuju bahwa komunikasi sesama teman di dalam kelas dan di luar kelas akan menciptakan hubungan yang mangkin baik.

j. Item 10: adalah Bagi saya komunikasi yang baik dengan dosen akan menciptakan hubungan yang semakin baik pula menunjukkan bahwa sebanyak $59,1 \%$ dari responden menjawab sangat setuju, $39,8 \%$ menjawab setuju, $1,1 \%$ yang menjawab kurang setuju, $0 \%$ yang menjawab tidak setuju dan $0,0 \%$ sangat tidak setuju. Maka dapat dikemukakan responden sangat setuju bahwa dengan komunikasi yang baik akan menjalin hubungan yang baik pula.

\section{Variabel Motivasi (X2)}

Pengukuran variabel Komunikasi dalam penelitian ini, peneliti menggunakan 4 indikator yang kemudian disajikan ke dalam 10 pernyataan. Pada setiap pernyataan terdapat 5 jawaban, dimana responden diharuskan menentukan jawaban mereka atau memilih salah satu alternatif jawaban yang telah disediakan oleh peneliti. Berdasarkan jawaban responden dari penyebaran kuisioner maka diperoleh hasilnya sebagai berikut:

1) Item 1: adalah Dalam melakukan suatu kegiatan saya butuh semangat agar pekerjaan bisa tercapai menunjukkan bahwa sebanyak 59, $1 \%$ dari responden menjawab sangat setuju, 38,6\% menjawab setuju, 2,3\% menjawab kurang setuju, $0 \%$ menjawab tidak setuju, dan $0 \%$ menjawab sangat tidak setuju. Maka dapat dikemukakan responden sangat setuju bahwa Dalam melakukan suatu kegiatan responden butuh semangat agar pekerjaan bisa tercapai. Karena dengan semangat yang tinggi, pekerjaan akan lebih mudah tecapai.

2) Item 2: adalah Saya melakukan pekerajaan sesuai dengan tujuan yang hendak dicapai menunjukkan bahwa sebanyak $43,2 \%$ dari responden menjawab sangat setuju, $53,4 \%$ menjawab setuju, $3,4 \%$ menjawab kurang setuju, 3,4\% menjawab tidak setuju dan sangat tidak setuju. Maka dapat dikemukakan responden sangat setuju bahwa responden melakukan pekerajaan sesuai dengan tujuan yang hendak dicapai. Karena dengan pekerjaan yang sesuai dengan tujuan maka tujuan dari pekerjaan tersebut akan mudah untuk dicapai.

3) Item 3: adalah Saya suka melakukan pekerjaan yang sulit karena akan menguji kemampuan yang ada pada diri saya menunjukkan bahwa sebanyak $13,6 \%$ dari responden menjawab sangat setuju, $54,5 \%$ menjawab setuju, $25 \%$ menjawab kurang setuju, 5,7\% menjawab tidak setuju dan $1,1 \%$ menjawab sangat tidak setuju. Maka dapat dikemukakan responden setuju bahwa suka melakukan pekerjaan yang sulit karena akan menguji kemampuan yang ada pada dirinya. Karena dengan melakukan pekerjaan yang sulit akan teruji kemampuan yang ada pada diri responden.

4) Item 4: adalah Saya lebih suka melakukan pekerjaan sesuai dengan aturan yang berlaku menunjukkan bahwa sebanyak $37,5 \%$ dari responden menjawab sangat setuju, $55,7 \%$ menjawab setuju, 5,7\% yang menjawab kurang setuju, 1, $1 \%$ yang menjawab tidak setuju dan $0 \%$ yang menjawab sangat tidak setuju. Maka dapat dikemukakan responden setuju bahwa responden 
lebih suka melakukan pekerjaan sesuai dengan aturan yang berlaku.

5) Item 5: adalah Saya akan terus berusaha dengan berbagai cara yang baik sehingga tercapai target saya menunjukkan bahwa sebanyak $55,7 \%$ dari responden menjawab sangat setuju, 40,9\% menjawab setuju, 3,4\% yang menjawab kurang setuju, 0\% yang menjawab tidak setuju dan tidak setuju. Maka dapat dikemukakan responden sangat setuju bahwa akan terus berusaha dengan berbagai cara yang baik sehingga tercapai target.

6) Item 6: adalah Saya akan lebih semangat belajar bila mendapat nilai yang bagus menunjukkan bahwa sebanyak 59, $1 \%$ dari responden menjawab sangat setuju, $33 \%$ menjawab setuju, 5,7\% yang menjawab kurang setuju, 2,3\% yang menjawab tidak setuju dan $0 \%$ sangat tidak setuju. Maka dapat dikemukakan responden sangat setuju bahwa responden akan lebih semangat belajar bila mendapat nilai yang bagus.

7) Item 7: adalah Bagi saya permasalah yang sulit saya anggap lebih menarik dari pada permasalahan yang sederhana menunjukkan bahwa sebanyak $11,4 \%$ dari responden menjawab sangat setuju, 51, 1\% menjawab setuju, $31,8 \%$ yang menjawab kurang setuju, 5,7\% yang menjawab tidak setuju dan $0 \%$ sangat tidak setuju. Maka dapat dikemukakan responden setuju bahwa permasalah yang sulit responden anggap lebih menarik dari pada permasalahan yang sederhana.

8) Item 8: adalah Saya lebih semangat mengerjakan sesuatu bila itu untuk di lombakan menunjukkan bahwa sebanyak $17 \%$ dari responden menjawab sangat setuju, 27,3\% menjawab setuju, 35,2\% yang menjawab kurang setuju, 14,8\% yang menjawab tidak setuju dan $5,7 \%$ sangat tidak setuju. Maka dapat dikemukakan responden kurang setuju bahwa semangat mengerjakan sesuatu bila itu untuk di lombakan.

9) Item 9: adalah Saya lebih tertarik dengan hal-hal yang menantang setiap permasalahan yang di hadapi menunjukkan bahwa sebanyak $11,4 \%$ dari responden menjawab sangat setuju, 54,5\% menjawab setuju, 26,1\% yang menjawab kurang setuju, 6,8\% yang menjawab tidak setuju dan $1,1 \%$ sangat tidak setuju. Maka dapat dikemukakan responden setuju bahwa lebih tertarik dengan hal-hal yang menantang setiap permasalahan yang di hadapi.

10) Item 10: adalah Saya berusaha ingin mengetahui lebih dulu dari temanteman setiap permasalahan menunjukkan bahwa sebanyak $26,1 \%$ dari responden menjawab sangat setuju, 56,8\% menjawab setuju, $13,6 \%$ yang menjawab kurang setuju, $1,1 \%$ yang menjawab tidak setuju dan 2,3\% sangat tidak setuju. Maka dapat dikemukakan responden setuju bahwa berusaha ingin mengetahui lebih dulu dari teman-teman setiap permasalahan.

\section{Variabel Kedisiplinan (X3)}

Pengukuran variabel Motivasi dalam penelitian ini, peneliti menggunakan 3 indikator yang kemudian disajikan ke dalam 10 pernyataan. Pada setiap pernyataan terdapat 5 jawaban, dimana responden diharuskan menentukan jawaban mereka atau memilih salah satu alternatif jawaban yang telah disediakan oleh peneliti. Berdasarkan jawaban responden dari penyebaran kuisioner maka diperoleh hasilnya sebagai berikut:

1) Item 1: adalah Saya lebih menghargai orang yang tepat waktu saat melakukan janji bertemu menunjukkan bahwa sebanyak 
$70,5 \%$ dari responden menjawab sangat setuju, 27,3\% menjawab setuju, 2,3\% menjawab kurang setuju, $0 \%$ menjawab tidak setuju dan menjawab sangat tidak setuju. Maka dapat dikemukakan responden sangat setuju bahwa lebih menghargai orang yang tepat waktu saat melakukan janji bertemu.

2) Item 2: adalah Saya lebih menghargai waktu setiap ada pertemuan yang sudah di sepakati bersama menunjukkan bahwa sebanyak 59,1\% dari responden menjawab sangat setuju, 40,9\% menjawab setuju, 0\% menjawab kurang setuju, tidak setuju dan sangat tidak setuju. Maka dapat dikemukakan responden sangat setuju bahwa komunikasi sesama teman itu penting untuk pembersatukan keputusan yang diambil. Karena dengan komunikasi sesama teman informasi yang didapat lebih lengkap.

3) Item 3: adalah Saya berprinsip disiplin waktu akan menciptakan kesuksesan di berbagai hal menunjukkan bahwa sebanyak 62,5 $\%$ dari responden menjawab sangat setuju, 36,4\% menjawab setuju, $1,1 \%$ menjawab kurang setuju, $0 \%$ menjawab tidak setuju dan menjawab sangat tidak setuju. Maka dapat dikemukakan responden setuju bahwa berprinsip disiplin waktu akan menciptakan kesuksesan di berbagai hal.

4) Item 4: adalah Bagi saya setiap orang yang taat peraturan bisa menjalankan tugas tepat waktu menunjukkan bahwa sebanyak $55,7 \%$ dari responden menjawab sangat setuju, $37,5 \%$ menjawab setuju, 5,7\% yang menjawab kurang setuju, $1,1 \%$ yang menjawab tidak setuju dan 0\% yang menjawab sangat tidak setuju. Maka dapat dikemukakan responden sangat setuju bahwa setiap orang yang taat peraturan bisa menjalankan tugas tepat waktu.

5) Item 5: adalah Bagi saya dengan kedisiplinan seseorang bisa bertanggung jawab atas pekerjaannya menunjukkan bahwa sebanyak 56,8\% dari responden menjawab sangat setuju, 38,6\% menjawab setuju, $4,5 \%$ yang menjawab kurang setuju, $0 \%$ yang menjawab tidak setuju dan sangat tidak setuju. Maka dapat dikemukakan responden sangat setuju bahwa Bagi responden dengan kedisiplinan seseorang bisa bertanggung jawab atas pekerjaannya.

6) Item 6: adalah Saya merasa kedisiplinan yang saya lakukan terbukti dengan hasil pembelajaran saya menunjukkan bahwa sebanyak $31,8 \%$ dari responden menjawab sangat setuju, 56,8\% menjawab setuju, $10,2 \%$ yang menjawab kurang setuju, $1,1 \%$ yang menjawab tidak setuju dan $0 \%$ sangat tidak setuju. Maka dapat dikemukakan responden sangat setuju bahwa kedisiplinan yang dilakukan terbukti dengan hasil pembelajaran responden.

7) Item 7: adalah Saya senang dengan disiplin yang di terapkan jurusan saat ini dalam proses belajar menunjukkan bahwa sebanyak $44,3 \%$ dari responden menjawab sangat setuju, 46,6\% menjawab setuju, $9,1 \%$ yang menjawab kurang setuju, $0 \%$ yang menjawab tidak setuju dan sangat tidak setuju. Maka dapat dikemukakan responden setuju bahwa senang dengan disiplin yang di terapkan jurusan saat ini dalam proses belajar.

8) Item 8: adalah Saya bisa menerima disiplin peraturan yang telah di tetapkan di Jurusan menunjukkan 
bahwa sebanyak $42 \%$ dari responden menjawab sangat setuju, $53,4 \%$ menjawab setuju, $4,5 \%$ yang menjawab kurang setuju, $0 \%$ yang menjawab tidak setuju dan sangat tidak setuju. Maka dapat dikemukakan responden setuju bahwa bisa menerima disiplin peraturan yang telah di tetapkan di Jurusan.

9) Item 9: adalah Saya bisa menerima setiap tugas yang di berikan Dosen dengan waktu yang telah di tetapkan menunjukkan bahwa sebanyak $29,5 \%$ dari responden menjawab sangat setuju, 46,6\% menjawab setuju, 21,6\% yang menjawab kurang setuju, 2,3\% yang menjawab tidak setuju dan 0\% sangat tidak setuju. Maka dapat dikemukakan responden sangat setuju bahwa bisa menerima setiap tugas yang di berikan Dosen dengan waktu yang telah di tetapkan.

10) Item 10: adalah Kadang-kadang saya lalai dengan waktu, ini merugikan saya sendiri menunjukkan bahwa sebanyak $39,9 \%$ dari responden menjawab sangat setuju, 48,9\% menjawab setuju, 6,8\% yang menjawab kurang setuju, 4,5\% yang menjawab tidak setuju dan $0 \%$ sangat tidak setuju. Maka dapat dikemukakan responden setuju bahwa kadangkadang responden lalai dengan waktu, ini merugikan diri sendiri.

\section{Variabel Prestasi Belajar (Y)}

Pengukuran variabel Prestasi Belajar dalam penelitian ini, peneliti menggunakan 2 indikator yang kemudian disajikan ke dalam 10 pernyataan. Pada setiap pernyataan terdapat 5 jawaban, dimana responden diharuskan menentukan jawaban mereka atau memilih salah satu alternatif jawaban yang telah disediakan oleh peneliti. Berdasarkan jawaban responden dari penyebaran kuisioner maka diperoleh hasil sebagai berikut:
1) Item 1: adalah Saya selalu menerapkan hidup sehat baik secara jasmani dan rohani menunjukkan bahwa sebanyak $31,8 \%$ dari responden menjawab sangat setuju, $58 \%$ menjawab setuju, $9,1 \%$ menjawab kurang setuju, $1,1 \%$ menjawab tidak setuju, dan $0 \%$ menjawab sangat tidak setuju. Maka dapat dikemukakan responden setuju bahwa selalu menerapkan hidup sehat baik secara jasmani dan rohani.

2) Item 2: adalah Bagi saya kesehatan utama agar semua bisa di kerjakan menunjukkan bahwa sebanyak $60,2 \%$ dari responden menjawab sangat setuju, 39,8\% menjawab setuju, $0 \%$ menjawab kurang setuju, $0 \%$ tidak setuju dan sangat tidak setuju. Maka dapat dikemukakan responden sangat setuju bahwa kesehatan paling utama agar semua bisa di kerjakan.

3) Item 3: adalah Bagi saya dengan sehat bisa meraih prestasi dalam belajar menunjukkan bahwa sebanyak 52,3\% dari responden menjawab sangat setuju, 39,8\% menjawab setuju, $8 \%$ menjawab kurang setuju, $0 \%$ menjawab tidak setuju dan menjawab sangat tidak setuju. Maka dapat dikemukakan responden sangat setuju bahwa dengan sehat bisa meraih prestasi dalam belajar.

4) Item 4: adalah Saya bisa menjaga kondisi agar tidak kelelahan dalam mengejar prestasi menunjukkan bahwa sebanyak $31,8 \%$ dari responden menjawab sangat setuju, $53,4 \%$ menjawab setuju, 14,8\% yang menjawab kurang setuju, $0 \%$ yang menjawab tidak setuju dan sangat tidak setuju. Maka dapat dikemukakan responden setuju bahwa menjaga kondisi agar tidak kelelahan dalam mengejar prestasi.

5) Item 5: adalah Bagi saya dukungan keluarga sangat berpengaruh dalam 
proses belajar menunjukkan bahwa sebanyak $72,7 \%$ dari responden menjawab sangat setuju, 26,1\% menjawab setuju, $1,1 \%$ yang menjawab kurang setuju, $0 \%$ yang menjawab tidak setuju dan $0 \%$ sangat tidak setuju. Maka dapat dikemukakan responden sangat setuju bahwa dukungan keluarga sangat berpengaruh dalam proses belajar.

6) Item 6: adalah Dengan dukungan keluarga ada ketenangan jiwa saya dalam menjalankan kuliah menunjukkan bahwa sebanyak $67 \%$ dari responden menjawab sangat setuju, 31,8\% menjawab setuju, $1,1 \%$ yang menjawab kurang setuju, $0 \%$ yang menjawab tidak setuju dan $0 \%$ sangat tidak setuju. Maka dapat dikemukakan responden sangat setuju bahwa dengan dukungan keluarga ada ketenangan jiwa saya dalam menjalankan kuliah.

7) Item 7: adalah Dalam pembelajaran pasilitas yang ada/ tersedia sangatlah mendukung dalam proses belajar mengajar menunjukkan bahwa sebanyak $51,1 \%$ dari responden menjawab sangat setuju, $42 \%$ menjawab setuju, $5,7 \%$ yang menjawab kurang setuju, $1,1 \%$ yang menjawab tidak setuju dan $0 \%$ sangat tidak setuju. Maka dapat dikemukakan responden sangat setuju bahwa Dalam pembelajaran pasilitas yang ada/ tersedia sangatlah mendukung dalam proses belajar mengajar.

8) Item 8: adalah Dalam meraih prestasi belajar, kurikulum yang baik dapat menunjang sistem pembelajaran menunjukkan bahwa sebanyak 44,3\% dari responden menjawab sangat setuju, $51,1 \%$ menjawab setuju, $4,5 \%$ yang menjawab kurang setuju, $0 \%$ yang menjawab tidak setuju dan sangat tidak setuju. Maka dapat dikemukakan responden setuju bahwa Dalam meraih prestasi belajar, kurikulum yang baik dapat menunjang sistem pembelajaran.

9) Item 9: adalah Dukungan teman, lingkungan dan media massa sangat berperanan penting terhadap prestasi yang di raih menunjukkan bahwa sebanyak 52,3\% dari responden menjawab sangat setuju, 40,9\% menjawab setuju, 5,7\% yang menjawab kurang setuju, 1,1\% yang menjawab tidak setuju dan $0 \%$ sangat tidak setuju. Maka dapat dikemukakan responden sangat setuju bahwa dukungan teman, lingkungan dan media massa sangat berperanan penting terhadap prestasi yang di raih.

10) Item 10: adalah Peranan jurusan terhadap mahasiswa yang berprestasi sangatlah penting, perlu di promosikan agar menjadi panutan untuk teman-teman yang lain menunjukkan bahwa sebanyak $51,1 \%$ dari responden menjawab sangat setuju, 43,2\% menjawab setuju, 4,5\% yang menjawab kurang setuju, $1,1 \%$ yang menjawab tidak setuju dan $0,0 \%$ sangat tidak setuju. Maka dapat dikemukakan responden sangat setuju bahwa Peranan jurusan terhadap mahasiswa yang berprestasi sangatlah penting, perlu di promosikan agar menjadi panutan untuk teman-teman yang lain.

\section{HASIL}

\section{a. Uji Validitas}

Uji validitas adalah tingkat keandalan alat ukur yang digunakan. Uji validitas digunakan untuk mengetahui kelayakan butir-butir dalam suatu daftar pertanyaan atau pernyataan dalam mendefinisikan variabel. Kriteria penilaian uji validitas adalah:

1. Apabila $r$ hitung $>r$ tabel, maka item kuesioner tersebut valid.

2. Apabila $r$ hitung < $r$ tabel, maka dapat dikatakan item kuesioner tidak valid. 
2.1 Variabel Kualitas Pelayanan (X1)

\begin{tabular}{|c|c|c|c|}
\hline Pernyataan & $\mathrm{r}_{\text {hitung }}$ & $\mathrm{r}_{\text {tabel }}$ & Ket \\
\hline 1 & $.576^{* *}$ & .270 & Valid \\
\hline 2 & $.625^{* *}$ & .270 & Valid \\
\hline 3 & $.698^{* *}$ & .270 & Valid \\
\hline 4 & $.678^{* *}$ & .270 & Valid \\
\hline 5 & $.569^{* *}$ & .270 & Valid \\
\hline 6 & $.453^{* *}$ & .270 & Valid \\
\hline 7 & $.660^{* *}$ & .270 & Valid \\
\hline 8 & $.635^{* *}$ & .270 & Valid \\
\hline 9 & $.616^{* *}$ & .270 & Valid \\
\hline 10 & $.600^{* *}$ & .270 & Valid \\
\hline
\end{tabular}

Sumber: Hasil Olahan Data Statistik (2020)

Berdasarkan tabel di atas dapat diketahui bahwa nilai $r$ hitung pada pernyataan 1 sampai 10 dalam kuisioner lebih besar dari $r$ tabel $(0,270)$. Dengan demikian, dapat disimpulkan bahwa semua pernyataan pada dalam indikator Komunikasi (X1) adalah valid dan dapat digunakan.

\subsection{Variabel Motivasi (X2)}

\begin{tabular}{|c|c|r|c|}
\hline Pernyataan & $\mathrm{r}_{\text {hitung }}$ & $\mathrm{r}_{\text {tabel }}$ & Ket \\
\hline 1 & $.357 * *$ & .270 & Valid \\
\hline 2 & $.444 * *$ & .270 & Valid \\
\hline 3 & $.592 * *$ & .270 & Valid \\
\hline 4 & $.430 * *$ & .270 & Valid \\
\hline 5 & $.604 * *$ & .270 & Valid \\
\hline 6 & $.448 * *$ & .270 & Valid \\
\hline 7 & $.435 * *$ & .270 & Valid \\
\hline 8 & $.655 * *$ & .270 & Valid \\
\hline 9 & $.594 * *$ & .270 & Valid \\
\hline 10 & $.540 * *$ & .270 & Valid \\
\hline
\end{tabular}

Sumber: Hasil Olahan Data Statistik (2020)

Berdasarkan tabel di atas dapat diketahui bahwa nilai $r$ hitung pada pernyataan 1 sampai 10 dalam kuisioner lebih besar dari $r$ tabel $(0,270)$. Dengan demikian, dapat disimpulkan bahwa semua pernyataan pada indikator Motivasi (X2) adalah valid dan dapat digunakan.

\subsection{Variabel Disiplin (X3)}

\begin{tabular}{|c|c|c|c|}
\hline Pernyataan & $\mathrm{r}_{\text {hitung }}$ & $\mathrm{r}_{\text {tabel }}$ & Ket \\
\hline 1 & $.586^{* *}$ & .270 & Valid \\
\hline
\end{tabular}

\begin{tabular}{|c|c|r|c|}
\hline 2 & $.620 * *$ & .270 & Valid \\
\hline 3 & $.676 * *$ & .270 & Valid \\
\hline 4 & $.767 * *$ & .270 & Valid \\
\hline 5 & $.799 * *$ & .270 & Valid \\
\hline 6 & $.626 * *$ & .270 & Valid \\
\hline 7 & $.724 * *$ & .270 & Valid \\
\hline 8 & $.702 * *$ & .270 & Valid \\
\hline 9 & $.617 * *$ & .270 & Valid \\
\hline 10 & $.406 * *$ & .270 & Valid \\
\hline
\end{tabular}

Sumber: Hasil Olahan Data Statistik (2020)

Berdasarkan tabel di atas dapat diketahui bahwa nilai $r$ hitung pada pernyataan 1 sampai 10 dalam kuisioner lebih besar dari $r$ tabel $(0,270)$. Dengan demikian, dapat disimpulkan bahwa semua pernyataan pada indikator Disiplin (X3) adalah valid dan dapat digunakan.

\subsection{Variabel Prestasi Belajar (Y)}

\begin{tabular}{|c|c|r|l|}
\hline Pernyataan & $\mathrm{r}_{\text {hitung }}$ & $\mathrm{r}_{\text {tabel }}$ & Ket \\
\hline 1 & $.466^{* *}$ & .270 & Valid \\
\hline 2 & $.739^{* *}$ & .270 & Valid \\
\hline 3 & $.741^{* *}$ & .270 & Valid \\
\hline 4 & $.648^{* *}$ & .270 & Valid \\
\hline 5 & $.667^{* *}$ & .270 & Valid \\
\hline 6 & $.712^{* *}$ & .270 & Valid \\
\hline 7 & $.593^{* *}$ & .270 & Valid \\
\hline 8 & $.630^{* *}$ & .270 & Valid \\
\hline 9 & $.726^{* *}$ & .270 & Valid \\
\hline 10 & $.583^{* *}$ & .270 & Valid \\
\hline
\end{tabular}

Sumber: Hasil Olahan Data Statistik (2020)

Berdasarkan tabel di atas dapat diketahui bahwa nilai $r$ hitung pada pernyataan 1 sampai 10 dalam kuisioner lebih besar dari $r$ tabel $(0,270)$. Dengan demikian, dapat disimpulkan bahwa semua pernyataan pada indikator Prestasi Belajar (Y) adalah valid dan dapat digunakan.

\section{b. Uji Reliabilitas}

Uji reliabilitas adalah Suatu ukuran yang menunjukkan tingkat kehandalan dalam suatu penelitian. Instrumen penelitian yang reliabel jika suatu instrumen berulang kali digunakan untuk mengukur objek yang sama akan menghasilkan data yang sama. Cara 
mengukurnya adalah dengan menghitung koefisien reliabelitas dan membandingkan dengan cronbanch's alpha yang bernilai 0,6 (lebih besar 0,6 maka reliabel, lebih kecil tidak reliabel). Pada penelitian ini digambarkan dengan cronbach's alpha>cronbach's standard $(0,6)$.

\begin{tabular}{|l|l|r|r|l|}
\hline No & \multicolumn{1}{|c|}{ Variabel } & $\begin{array}{c}\text { cronbach's } \\
\text { alpha }\end{array}$ & $\begin{array}{c}\text { cronbach's } \\
\text { standard }\end{array}$ & Ket \\
\hline 1 & $\begin{array}{l}\text { Komunikasi } \\
\text { (X1) }\end{array}$ & .804 & .60 & Reliabel \\
\hline 2 & Motivasi (X2) & .685 & .60 & Reliabel \\
\hline 3 & Disiplin (X3) & .685 & .60 & Reliabel \\
\hline 4 & $\begin{array}{l}\text { Prestasi } \\
\text { Belajar (Y) }\end{array}$ & .841 & .60 & Reliabel \\
\hline
\end{tabular}

Sumber: Hasil Olahan Data Statistik (2020)

\section{c. Uji Asumsi Klasik \\ c.1 Uji Heterokedastisitas}

Uji heteroskedastisitas menguji terjadinya perbedaan variance residual suatu periode pengamatan ke periode yang lain. Data yang baik adalah yang tidak terjadi heterokedastisitas. Dasar pengambilan keputusan adalah jika pola tertentu seperti titik-titik yang ada membentuk suatu pola yang teratur, maka terjadi heterokedasitas. Jika tidak ada pola yang jelas serta titik-titik menyebar di bawah dan di atas angka 0 pada sumbu Y, maka tidak terjadi heterokedastisitas. Gambar-1 Hasil Uji Heterokedastisitas dengan Scatterplot.

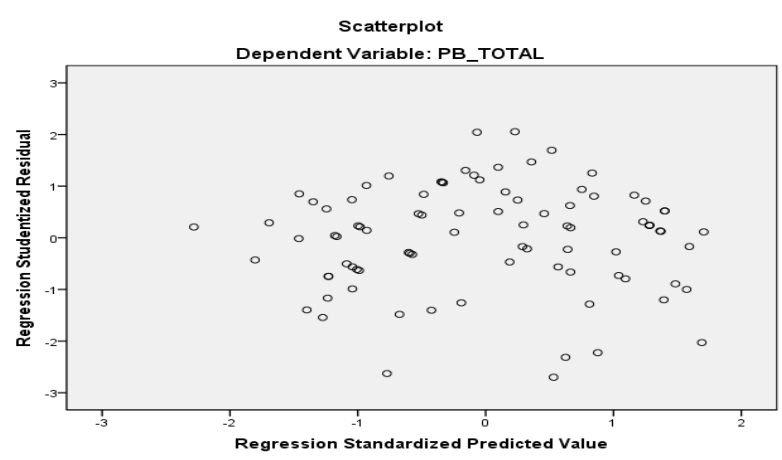

Sumber: Hasil Olahan SPSS

\section{c. 2 Uji Normalitas}

Pengujian distribusi normal ini digunakan normal probability plot. Sebaran normal merupakan sebuah pendekatan fungsi dari suatu kumpulan yang memiliki ciri khas, seperti pengamatan yang paling banyak dijumpai memiliki nilai di sekitar nilai tengah (mean), pengamatan yang sangat jauh (ke arah kanan dan kiri mean) berjumlah sedikit sekali, memiliki pola yang simetris. Menurut Santoso (2000:214), Salah satu cara untuk menguji kenormalan adalah Uji Chi Square, untuk menentukan apakah sebaran data normal atau tidak, dapat dilihat dan nilai probabilitas dibandingkan dengan $\alpha$. Jika nilai probabilitas $<\alpha$ berarti data tersebar normal. Gambar-2 Hasil Uji Normalitas probability plot.

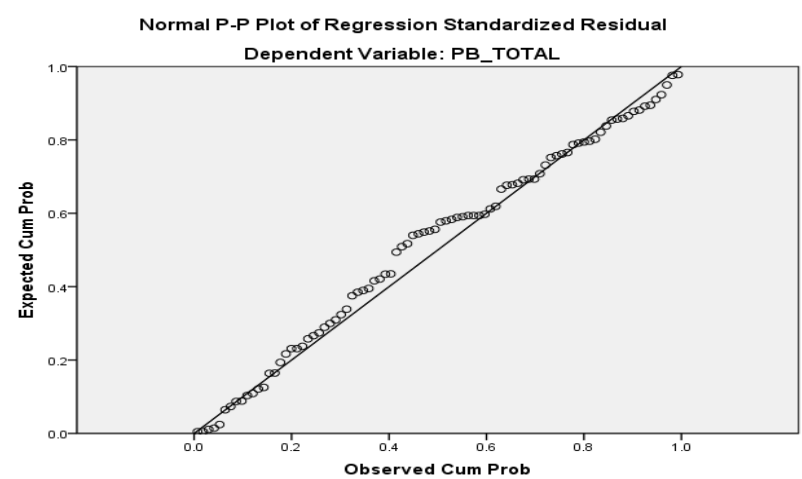

Sumber: Hasil Olahan SPSS

Pada Gambar 2 grafik normal probability plot terlihat titik-titik menyebar di sekitar garis diagonal, serta penyebarannya mengikuti arah garis diagonal. Sehingga model regresi sesuai dengan asumsi normalitas karena memenuhi kriteria normalitas analisis grafik yang pertama yaitu data berdistribusi normal.

\section{c.3 Uji Multikolinearitas}

Uji multikolonieritas diperlukan untuk mengetahui ada tidaknya variabel independen yang memiliki hubungan antar variabel independen dalam suatu model. Hubungan antar variabel independen akan mengakibatkan korelasi yang sangat kuat. Untuk multikolonieritas dapat dilakukan dengan melihat nilai TOL (Tolerance) dan VIF (Variance Inflation Factor) dari masing-masing variabel bebas dan variabel terikatnya. Jika nilai VIF tidak lebih dari 10 dan nilai TOL lebih dari 0,1 maka model 
dinyatakan tidak terdapat gejala multikolonier. Hasil Uji Multikolonieritas

\begin{tabular}{|c|c|c|}
\hline \multirow{2}{*}{ Model } & \multicolumn{2}{|c|}{ Collinearity Statistics } \\
\hline & Tolerance & VIF \\
\hline $1 \quad$ (Constant) & & \\
\hline K_TOTAL & .543 & 1.842 \\
\hline M_TOTAL & .653 & 1.532 \\
\hline D_TOTAL & .579 & 1.727 \\
\hline
\end{tabular}

Pada tabel menunjukkan tidak ada variabel yang memiliki nilai tolerance kurang dari 0,1 dan nilai VIF juga menunjukkan tidak ada satu variabel independen yang memiliki nilai VIF lebih dari 10. Jadi dapat disimpulkan bahwa tidak ada multikolonieritas antar variabelindependen dalam model regresi.

\section{c.4 Analisis Regresi Linier Berganda}

Analisis regresi linier berganda digunakan untuk mengetahui seberapa besar pengaruh variabel independen komunikasi, motivasi dan kedisiplinan terhadap variabel dependen prestasi belajar. Adapun bentuk persamaan regresi linier berganda adalah sebagai berikut:

$$
Y=a+b 1 X 1+b 2 X 2+b 3 X 3+e
$$

Keterangan:

$$
\begin{array}{ll}
\mathrm{Y} & =\text { prestasi belajar } \\
a & =\text { intercept } \text { (konstanta) } \\
b 1 & =\text { koefisien regresi untuk X1 } \\
\mathrm{X} 1 & =\text { komunikasi } \\
b 2 & =\text { koefisien regresi untuk X2 } \\
\mathrm{X} 2 & =\text { motivasi } \\
B 3 & =\text { koefisien regresi untuk X2 } \\
\mathrm{X} 3 & =\text { kedisiplinan } \\
e & =\text { error (nilai residu) }
\end{array}
$$

Berdasarkan pengujian menggunakan software statistic, maka hasil persamaan regresi linier berganda dapat dilihat sebagai berikut:

\begin{tabular}{|c|r|r|r|r|r|}
\hline \multirow{2}{*}{ Model } & \multicolumn{2}{|c|}{$\begin{array}{c}\text { Unstandardized } \\
\text { Coefficients }\end{array}$} & $\begin{array}{c}\text { Standardized } \\
\text { Coefficients }\end{array}$ & \multirow{2}{*}{$\mathrm{t}$} & \multirow{2}{*}{ Sig. } \\
\cline { 2 - 4 } & \multicolumn{1}{c|}{ B } & \multicolumn{1}{c|}{$\begin{array}{c}\text { Std. } \\
\text { Error }\end{array}$} & \multicolumn{1}{|c|}{ Beta } & & \\
\hline 1 (Constant) & 5.787 & 3.457 & & 1.674 & .098 \\
K_TOTAL & .181 & .098 & .166 & 1.846 & .068 \\
M_TOTAL & .137 & .082 & .137 & 1.675 & .098 \\
D_TOTAL & .574 & .084 & .597 & 6.863 & .000 \\
\hline
\end{tabular}

Sumber: Hasil Olahan SPSS

Berdasarkan tabel model-model persamaan regresi yang terbentuk adalah:

\section{$Y=5,787+0,181 \times 1+0,137 X 2+0,574 X 3+e$}

Berdasarkan persamaan tersebut dapat diketahui bahwa:

Apabila seluruh variabel independen (X1, X2, x3) dianggap konstan maka nilai keputusan Pembelian (Y) adalah sebesar 5,787 dengan e (standar error) tetap dan tidak berubah. Dapat dilihat juga bahwa nilai koefisien regresi komunikasi sebesar 0,181 lebih kecil dibandingkan dengan nilai koefisien regresi motivasi sebesar 0,137 dan lebih kecil dibandingkan dengan nilai koefisien regresi disiplin. Hal tersebut dapat diartikan bahwa variabel disiplin mempunyai pengaruh yang lebih besar terhadap prestasi belajar dibandingkan dengan variabel komunikasi dan motivasi.

\section{d. Pengujian Hipotesis \\ d.1 Uji Parsial (Uji-t)}

Uji Signifikan Parsial (uji t) digunakan untuk menunjukan seberapa jauh pengaruh antar variabel independen dengan variabel dependen. Apabila nilai probalitas signifikan lebih kecil dari 0,05 (5\%) maka suatu variabel independen berpengaruh signifikan terhadap variabel dependen. Adapun kriteria adalah:

1. Jika $\mathrm{t}$ hitung $>\mathrm{t}$ tabel maka Ho ditolak dan Ha diterima.

2. Jika $\mathrm{t}$ hitung $<\mathrm{t}$ tabel maka Ho diterima dan Ha ditolak. 
Menentukan $\mathrm{t}$ tabel dengan melihat pada $\alpha=5 \%$ yang diperoleh dari degree of freedom dengan rumus: $\mathrm{df}=\mathrm{n}-\mathrm{k}$

Keterangan:

$\mathrm{df}=$ degree offreedom (derajat)

$\mathrm{n}=$ jumlah sampel yang digunakan dalam penelitian yaitu 88

$\mathrm{k}=$ jumlah variabel yang digunakan dalam penelitian yaitu 3 sehingga $t$ tabel dengan sampel 88, probabilitas 5\% dan df sebesar 93 adalah 1,66298 Berikut adalah tabel uji t dari statistic software:

\begin{tabular}{|c|r|r|r|r|r|}
\hline \multirow{2}{*}{ Model } & \multicolumn{2}{|c|}{$\begin{array}{l}\text { Unstandardized } \\
\text { Coefficients }\end{array}$} & $\begin{array}{c}\text { Standardized } \\
\text { Coefficients }\end{array}$ & \multirow{2}{*}{$\mathrm{t}$} & Sig. \\
\cline { 2 - 4 } & \multicolumn{1}{c|}{ B } & $\begin{array}{c}\text { Std. } \\
\text { Error }\end{array}$ & Beta & & \\
\hline 1 (Constant) & 5.787 & 3.457 & & 1.674 & .098 \\
K_TOTAL & .181 & .098 & .166 & 1.846 & .068 \\
M_TOTAL & .137 & .082 & .137 & 1.675 & .098 \\
D_TOTAL & .574 & .084 & .597 & 6.863 & .000 \\
\hline
\end{tabular}

\section{Sumber: Hasil Olahan SPSS}

Pengujian hipotesis untuk variabel komunikasi, motivasi dan disiplin dapat dilihat pada tabel dengan penjabaran sebagai berikut:

1. Variabel komunikasi secara parsial berpengaruh secara positif dan namun tidak signifikan terhadap prestasi belajar, hal ini dapat dilihat dari nilai thitung (1.846) > ttabel (0.270) dan nilai signifikan $(0,068)>0,05$, maka hipotesis (H1) diterima.

2. Variabel motivasi secara parsial berpengaruh secara positif namun tidak signifikan terhadap prestasi belajar, hal ini dapat dilihat dari nilai thitung $(1,675)$ $>\mathrm{t}$ tabel $(0.270)$ dan nilai signifikan $(0,098)>0,05$, maka hipotesis $(\mathrm{H} 2)$ diterima.

3. Variabel Disiplin secara parsial berpengaruh secara positif dan signifikan terhadap prestasi belajar, hal ini dapat dilihat dari nilai thitung $(6,863)$ $>\mathrm{t}$ tabel (0.270) dan nilai signifikan $(0,000)<0,05$, maka hipotesis $(\mathrm{H} 3)$ diterima.

\section{e. Uji Simultan (Uji F)}

Uji signifikansi simultan (uji F) digunakan untuk mengukur seberapa jauh pengaruh variabel independen secara bersama-sama dalam menerangkan variabel dependen. Kriteria penerimaan/ penolakan hipotesis dengan tingkat $\alpha=0,05$ apabila tingkat signifikansi dibawah 0,05 maka hipotesis diterima, dan begitu sebaliknya. Selanjunya untuk nilai $\mathrm{F}$ ditentukan sebagai berikut:

1. Jika nilai $\mathrm{F}$ hitung $>\mathrm{F}$ tabel maka hipotesis diterima.

2. Jika nilai $\mathrm{F}$ hitung $<\mathrm{F}$ tabel maka hipotesis ditolak.

Menentukan Ftabel dengan melihat pada $\alpha=5 \%$, yang diperoleh dari degree of freedom untuk pembilang dan degree of freedom untuk penyebut dengan rumus:

df pembilang $=\mathrm{k}-1$

df pembilang $=3-1$

df penyebut $=\mathrm{n}-\mathrm{k}-1$

$$
=88-3-1
$$

Keterangan:

$\mathrm{df}=$ degree of freedom (derajat)

$\mathrm{n}=$ jumlah sampel yang digunakan dalam penelitian yaitu 88

$\mathrm{k}=$ jumlah variabel yang digunakan dalam penelitian yaitu 3

Sehingga Ftabel dengan sampel 88, probabilitas $5 \%$ dan df pembilang 2 , df penyebut 84 adalah 2,71. Berikut adalah tabel uji F dari statistic software:

\begin{tabular}{|l|r|r|r|c|c|}
\hline \multicolumn{1}{|c|}{ Model } & $\begin{array}{c}\text { Sum of } \\
\text { Squares }\end{array}$ & Df & $\begin{array}{c}\text { Mean } \\
\text { Square }\end{array}$ & F & Sig. \\
\hline 1 Regression & 815.725 & 3 & 271.908 & 48.160 & $.000^{\text {a }}$ \\
Residual & 474.263 & 84 & 5.646 & & \\
Total & 1289.989 & 87 & & & \\
\hline
\end{tabular}

Sumber: Hasil Olahan SPSS

a. Predictors: (Constant), D_TOTAL, M_TOTAL, TOTAL_K

b. Dependent Variable: PB_TOTAL

Pengujian hipotesis dapat dilihat dari tabel di atas, bahwa nilia F hitung $(48,160)$ $>$ F tabel $(2,71)$ dan nilai signifikan $(0,000)$ $<0,05$, maka hipotesis (H3) diterima. Hal ini menunjukkan bahwa variabel 
independen yang terdiri dari Komunikasi (X1), Motivasi (X2) dan Disiplin (X3) secara simultan atau bersama-sama berpengaruh positif dan signifikan terhadap variabel dependen Prestasi Belajar (Y).

\subsection{Uji Koefisien Determinasi (R2)}

Tujuan analisis ini adalah untuk menghitung besarnya pengaruh variabel independen terhadap variabel dependen. Semakin tinggi nilai R2 maka semakin besar proporsi dari total variasi variabel dependen yang dapat dijelaskan oleh variabel independen.

\begin{tabular}{|c|r|r|r|r|}
\hline Model & \multicolumn{1}{|c|}{$\mathrm{R}$} & $\begin{array}{c}\mathrm{R} \\
\text { Square }\end{array}$ & $\begin{array}{l}\text { Adjusted } \\
\text { R Square }\end{array}$ & $\begin{array}{l}\text { Std. Error of } \\
\text { the Estimate }\end{array}$ \\
\hline 1 & $.795^{\mathrm{a}}$ & .632 & .619 & 2.376 \\
\hline
\end{tabular}

Sumber: Hasil Olahan SPSS

Hasil Penelitian ini berdasarkan dari adanya data dan analisa yang telah dilakukan, sehingga dengan bantuan software statistic dapat diketahui bahwa komunikasi, motivasi dan disiplin mempunyai pengaruh yang positif dan signifikan baik secara simultan terhadap prestasi belajar pada Mahasiswa Jurusan Administrasi Bisnis Politeknik Negeri Pontianak. Hasil tersebut sesuai dengan hipotesis yang ditujukan, sehingga hipotesis dapat diterima.

\section{PEMBAHASAN}

a. Pengaruh Komunikasi terhadap Prestasi Belajar

\begin{tabular}{|c|r|r|r|r|r|}
\hline \multirow{2}{*}{ Model } & \multicolumn{2}{|c|}{$\begin{array}{c}\text { Unstandardized } \\
\text { Coefficients }\end{array}$} & $\begin{array}{c}\text { Standardized } \\
\text { Coefficients }\end{array}$ & \multirow{2}{*}{$\mathrm{t}$} & \multirow{2}{*}{ Sig. } \\
\cline { 2 - 4 } & \multicolumn{1}{|c|}{$\mathrm{B}$} & Std. Error & \multicolumn{1}{|c|}{ Beta } & & \\
\hline 1 (Constant) & \multicolumn{1}{|c|}{5.787} & 3.457 & & 1.674 & .098 \\
& & & & & \\
K_TOTAL & .181 & .098 & .166 & 1.846 & .068 \\
M_TOTAL & .137 & .082 & .137 & 1.675 & .098 \\
D_TOTAL & .574 & .084 & .597 & 6.863 & .000 \\
\hline
\end{tabular}

Berdasarkan hasil pengujian regresi tentang pengaruh Komunikasi terhadap Prestasi Belajar diperoleh nilai Sig. sebesar
0,068 dengan nilai koefisien beta 0,181. Nilai Sig. 0,038>0,05 mengindikasikan bahwa $\mathrm{H}_{1}$ ditolak. Hasil ini mempunyai arti bahwa Komunikasi tidak berpengaruh siginifikan terhadap Prestasi Belajar pada Mahasiswa Jurusan Administrasi Bisnis Politeknik Negeri Pontianak.

1. Pengaruh Motivasi Terhadap Prestasi Belajar (Uji Persial/ Uji T)

\begin{tabular}{|c|r|r|c|r|r|}
\hline \multirow{2}{*}{ Model } & \multicolumn{2}{|c|}{$\begin{array}{c}\text { Unstandardized } \\
\text { Coefficients }\end{array}$} & $\begin{array}{c}\text { Standardized } \\
\text { Coefficients }\end{array}$ & \multirow{2}{*}{$\mathrm{t}$} & \multirow{2}{*}{ Sig. } \\
\cline { 2 - 4 } & \multicolumn{1}{|c|}{ B } & Std. Error & Beta & & \\
\hline 1 (Constant) & 5.787 & 3.457 & & 1.674 & .098 \\
K_TOTAL & .181 & .098 & .166 & 1.846 & .068 \\
M_TOTAL & .137 & .082 & .137 & 1.675 & .098 \\
D_TOTAL & .574 & .084 & .597 & 6.863 & .000 \\
\hline
\end{tabular}

Sumber: Hasil Olahan SPSS

Berdasarkan hasil pengujian regresi tentang pengaruh Motivasi terhadap Prestasi Belajar diperoleh nilai Sig. sebesar 0,098 dengan nilai koefisien beta 0,137. Nilai Sig. 0,098>0,05 mengindikasikan bahwa $\mathrm{H}_{1}$ ditolak. Hasil ini mempunyai arti bahwa Motivasi tidak berpengaruh terhadap Prestasi Belajar pada Mahasiswa Jurusan Administrasi Bisnis Politeknik Negeri Pontianak.

2. Pengaruh Kedisiplinan Terhadap Prestasi Belajar (Uji Parsial/ Uji T)

\begin{tabular}{|c|c|c|c|c|c|}
\hline \multirow{2}{*}{ Model } & \multicolumn{2}{|c|}{$\begin{array}{l}\text { Unstandardized } \\
\text { Coefficients }\end{array}$} & \multirow{2}{*}{$\begin{array}{c}\begin{array}{c}\text { Standardized } \\
\text { Coefficients }\end{array} \\
\text { Beta }\end{array}$} & \multirow{2}{*}{$\mathrm{t}$} & \multirow{2}{*}{ Sig. } \\
\hline & B & $\begin{array}{l}\text { Std. } \\
\text { Error }\end{array}$ & & & \\
\hline \multirow{4}{*}{$\begin{array}{l}\text { K_TOTAL } \\
\text { M_TOTAL } \\
\text { D_TOTAL }\end{array}$} & 5.787 & 3.457 & & 1.674 & .098 \\
\hline & .181 & .098 & .166 & 1.846 & .068 \\
\hline & .137 & .082 & .137 & 1.675 & .098 \\
\hline & .574 & .084 & .597 & 6.863 & .000 \\
\hline
\end{tabular}

\section{Sumber: Hasil Olahan SPSS}

Berdasarkan hasil pengujian regresi tentang pengaruh Motivasi terhadap Prestasi Belajar diperoleh nilai Sig. sebesar 0,098 Berdasarkan hasil pengujian regresi tentang pengaruh Kedisiplinan terhadap Prestasi Belajar diperoleh nilai Sig. sebesar 
0,000 dengan nilai koefisien beta 0,574. Hal ini menunjukan bahwa ketika Kedisiplinan semakin baik maka Prestasi Belajar juga semakin tinggi. Nilai Sig. $0,000<0,05$ mengindikasikan bahwa $\mathrm{H}_{1}$ diterima. Hasil ini mempunyai arti bahwa Kedisiplinan berpengaruh terhadap Prestasi Belajar pada Mahasiswa Jurusan Administrasi Bisnis Politeknik Negeri Pontianak.

3. Pengaruh Komunikasi, Motivasi dan Kedisiplinan Terhadap Prestasi Belajar Hasil Uji Simultan (Uji F)

\begin{tabular}{|c|c|c|c|c|c|}
\hline \multicolumn{6}{|c|}{ ANOVA $^{b}$} \\
\hline Model & $\begin{array}{l}\text { Sum of } \\
\text { Squares }\end{array}$ & Df & $\begin{array}{l}\text { Mean } \\
\text { Square }\end{array}$ & $\mathrm{F}$ & Sig. \\
\hline 1 Regression & 815.725 & 3 & 271.908 & 48.160 & $.000^{\mathrm{a}}$ \\
\hline Residual & 474.263 & 84 & 5.646 & & \\
\hline Total & 1289.989 & 87 & & & \\
\hline
\end{tabular}

Sumber: Hasil Olahan SPSS

a. Predictors: (Constant), D_TOTAL, M_TOTAL, TOTAL_K b. Dependent Variable: PB_TOTAL

Berdasarkan hasil perhitungan Tabel di atas didapat nilai $F_{\text {hitung }} 48,160$ dan nilai $F_{\text {tabel }}$ 2,70 dengan nilai signifikansi 0,000 . Hal ini berarti nilai $F_{\text {hitung }}>F_{\text {tabel }}$ dan sig < 0,05 sehingga dapat disimpulkan bahwa $\mathrm{H}_{1}$ diterima. Artinya terdapat pengaruh secara bersamaan (simultan) antara variabel Komunikasi, Motivasi dan Kedisiplinan terhadap Prestasi Belajar pada Mahasiswa Jurusan Administrasi Bisnis Politeknik Negeri Pontianak.

\section{SIMPULAN}

Dari pembahasan hasil olahan data yang peneliti lakukan maka dapat di simpulkan berdasarkan tujuan dari penelitian yaitu:

a. Pengaruh komunikasi terhadap prestasi Belajar Mahasiswa, Variabel komunikasi secara parsial berpengaruh secara positif dan namun tidak signifikan terhadap prestasi belajar, hal ini dapat dilihat dari nilai thitung $(1.846)>$ tabel $(0.270)$ dan nilai signifikan $(0,068)>0,05$, maka hipotesis (H1) diterima. b. Pengaruh motivasi terhadap prestasi belajar mahasiswa. variabel motivasi secara parsial berpengaruh secara positif namun tidak signifikan terhadap prestasi belajar, hal ini dapat dilihat dari nilai thitung $(1,675)>$ ttabel $(0.270)$ dan nilai signifikan $(0,098)>0,05$, maka hipotesis $(\mathrm{H} 2)$ diterima.

c. Pengaruh kedisiplinan terhadap prestasi mahasiswa, variabel Disiplin secara parsial berpengaruh secara positif dan signifikan terhadap prestasi belajar, hal ini dapat dilihat dari nilai thitung $(6,863)>t$ tabel $(0.270)$ dan nilai signifikan $(0,000)<0,05$, maka hipotesis (H3) diterima.

Pengaruh komunikasi, motivasi dan kedisiplinan terhadap prestasi belajar, variabel komunikasi dan motivasi secara parsial berpengaruh secara positif. Berdasarkan hasil perhitungan Tabel 17 didapat nilai $F_{\text {hitung }} 48,160$ dan nilai $F_{\text {tabel }}$ 2,70 dengan nilai signifikansi 0,000 . Hal ini berarti nilai $\mathrm{F}_{\text {hitung }}>\mathrm{F}_{\text {tabel }}$ dan sig $<0,05$ sehingga dapat disimpulkan bahwa $\mathrm{H}_{1}$ diterima. Artinya terdapat pengaruh secara bersamaan (simultan) antara variabel Komunikasi, Motivasi dan Kedisiplinan terhadap Prestasi Belajar pada Mahasiswa Jurusan Administrasi Bisnis Politeknik Negeri Pontianak.

\section{REFERENSI}

\section{Sumber Buku:}

A.M Sardiman. 2012. Interaksi \& Motivasi Belajar Mengajar. Jakarta. Rajawali.

Abraham H. Maslow. 2010. Motivation and Personality. Jakarta. Rajawali.

Arifin, Zainal. 2011. Evaluasi Pembelajaran. Bandung. PT. Remaja. Rosdakarya.

Arikunto, S. 2002. Metodologi Penelitian Suatu Pendekatan Proposal. Jakarta. PT. Rineka Cipta.

Azhar, Susanto. 2010. Sistem Informasi 1, Pendekatan Normal Praktiuka. Penyusunan Metode dan Prosedur. Edisi 5. Bandung. Lingga. 
Davis Keith. 2010. Terjemahan Agus Dharma. Perilaku Dalam Organisasi. Jakarta. Erlangga.

Dimyati dan Mudjiono. 2009. Belajar dan Pembelajaran. Jakarta. Rineka Cipta.

Djamarah, Syaiful Bahri. 2011. Psikologi Belajar. Jakarta. Rineka Cipta.

Hamalik, Oemar. 2004. Pendidikan Guru Berdasarkan Pendekatan Kompetensi. Jakarta. Bumi Aksara.

Hariandja. 2002. Manajemen Sumber Daya Manusia. Grasindo. Jakarta.

Hasibuan Melayu. 2002. Manajemen Sumber Daya Manusia. Jakarta. Bumi Aksara.

Husein, Umar. 2004. Skala Pengukuran Variabel Penelitian. Bandung. Alfabeta Persada.

Riduwan. 2006. Metode dan Teknik Menyusun Tesis. Bandung. Alfabeta.

Robbins, P. Stephen. 2002. Prinsip-Prinsip Perilaku Organisasi. Edisi Kelima. Diterjemahkan oleh: Halida, S.E dan Dewi Sartika, S.S. Erlangga. Jakarta.

Santoso, Singgih, dan Fandy Tjiptono. 2002. Riset Pemasaran: Konsep dan. Aplikasinya dengan SPSS. Jakarta. PT Elex Media.

Santoso, Singgih. 2000. SPSS: Statistik Parametrik. Elek Media Komputindo. Jakarta.

Santoso, Slamet. 2010. Teori Psikologi Sosial. Bandung. PT. Rafika Aditama

Sinambela, Lijan Poltak. 2016. Manajemen Sumber Daya Manusia: Membangun Tim Yang Solid Untuk Meningkatkan Kinerja. Jakarta. PT Bumi Aksara.

Singarimbun, Masri dan Effenfi Sofian. 1999. Metode Penelitian Survey. Jakarta. LP3ES.

Slameto. 2010. Belajar dan Faktor-Faktor yang Mempengaruhinya, Jakarta. Rineka Cipta.

Supardi. 2005. Metode Penelitian Ekonomi dan Bisnis. Yogyakarta.UII Press.

Sutrisno, Edy. 2010. Manajemen Sumber Daya Manusia. Edisi 1. Cetakan Kedua. Jakarta. Prenada Media Group.
Winardi. 2002. Motivasi dan Pemotivasian dalam Manajemen. Jakarta. PT Raja Grafindo.

\section{Jurnal:}

Denok Sunarsi. 2018. Pengaruh Disiplin, Motivasi dan Kompetensi Terhadap Prestasi Belajar (Studi Kasus Pada Mahasiswa Universitas Pamulang, Tangerang Selatan Tahun Akademik 2016-2017). Jurnal Mandiri: Ilmu Pengetahuan, Seni, Dan Teknologi, Vol 1(2). 207-226. https://doi.org/10.33753/mandiri.v1i 2.19

Syamsu Alam. 2019. Pengaruh Komunikasi, Motivasi dan Disiplin Kerja Terhadap Kinerja Pegawai Lembaga Penjamin Mutu Pendidikan. (Program Studi Magister Managemen Pascasarjana Universitas Tadulako). e-Jurnal Katalogis. Vol 2(1). Januari 2019. hal 135-145. 